\title{
Cosmogenic nuclide ages for Last Glacial Maximum moraine at Schnells Ridge, Southwest Tasmania
}

\author{
Kevin Kiernan, ${ }^{a}$ L. Keith Fifield, ${ }^{\mathrm{b}}$ and John Chappell ${ }^{\mathrm{c}, *}$

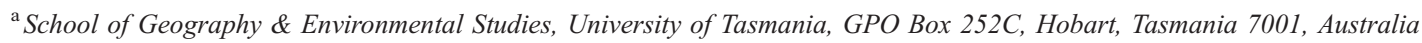 \\ ${ }^{\mathrm{b}}$ Department of Nuclear Physics, Research School of Physical Sciences and Engineering, Australian National University, ACT 0200, Australia \\ ${ }^{\mathrm{c}}$ Research School of Earth Sciences, Australian National University, ACT 0200, Australia
}

Received 6 February 2000

Available online 27 April 2004

\begin{abstract}
Moraines on Schnells Ridge, southwest Tasmania, have been dated using in situ ${ }^{10} \mathrm{Be}$. An age of $19,400 \pm 600 \mathrm{yr}$ is indicated for the wellpreserved innermost moraine from consistent measurements on four large quartzite boulders. This corresponds closely with exposure ages reported by T.T. Barrows et al. (2002, Quaternary Science Reviews 21, 159-173) for Last Glacial Maximum glacial features farther north in Tasmania and southeast Australia. In contrast, ages between 39,000 and 141,000 yr were obtained from a series of boulders on a more extensive outer moraine, indicating that this has had a more complex history.
\end{abstract}

(C) 2004 Published by University of Washington.

Keywords: Glaciation; Tasmania; Cosmogenic nuclide dating

\section{Introduction}

There are no glaciers in Australia today, but evidence for Pleistocene glaciation is preserved in moraines and glacial valleys in Tasmania and, on a smaller scale, in the Snowy Mountains of New South Wales. The latest major glacial advance in southeastern Australia was equated to the global Last Glacial Maximum (LGM) by Colhoun (1985), but dated evidence was sparse until Barrows et al. (2001, 2002) applied exposure-age methods. Using cosmogenic ${ }^{10} \mathrm{Be}$ and ${ }^{36} \mathrm{Cl}$, these authors established an LGM age of 17,000-20,000 for moraines in the Snowy Mountains (BL-III and LC-I moraines) and in Tasmania (12 moraines in eight glaciated areas). They also reported ages indicating glacial advances during marine oxygen isotope stages 3 and 4 (MIS 3 and 4) and during MIS 6 or earlier.

This Short Paper reports cosmogenic ${ }^{10} \mathrm{Be}$ dates from moraines at Schnells Ridge in Southwest Tasmania $\left(43^{\circ} 02^{\prime} \mathrm{S}\right.$, $146^{\circ} 25^{\prime} \mathrm{E}$ ), previously described by Kiernan (1990). Results

\footnotetext{
* Corresponding author.

E-mail address: john.chappell@anu.edu.au (J. Chappell).
}

show that the last major glacier advance at this site occurred $19,400 \pm 600$ yr ago (four dates), in close agreement with the LGM results from farther north reported by Barrows et al. (2002). We also report dates from an older, composite moraine that represents an advance beyond the LGM limit at Schnells ridge, which appears to have been activated several times, including during MIS 4.

\section{Study site}

Schnells Ridge rises above the southern end of the deep glacial trough of Lake Judd, which descends southward from the Mt. Anne massif (Kiernan, 1990). Moraines in the area originate both from the Lake Judd Glacier and from glaciers on Schnells Ridge. At some stages, ice from the two sources was confluent. Kiernan (1990) recognized four glaciations, which in order of increasing age he termed the Judd, Timk, Weld, and Eliza stages. On the basis of morphologic relationships and thicknesses of weathering rinds on dolerite boulders within the moraines, the Judd stage was thought to represent the LGM; the Timk and Weld stages were interpreted as predating the last interglaciation, and the 
Eliza stage was inferred to be no younger than Early Pleistocene (Kiernan, 1990).

The study site is the western side of Smith's Tarn valley, which cuts deeply into Precambrian quartzite and metamorphic rocks of Schnells Ridge (Fig. 1). Large glacial boulders were sampled from two well-defined lateral moraine ridges on and immediately behind the valley shoulder (Figs. 1 and 2). Separated by a shallow swale $\sim 150 \mathrm{~m}$ wide, these moraines rise boldly above the buried bedrock surface and contain large angular quartzite blocks, some striated. The inner moraine represents the Judd glacial stage, assigned to the LGM by Kiernan
(1990); it forms a sharp-crested wall above Smith's Tarn valley and descends from $780 \mathrm{~m}$ to a steep nose at $\sim 670$ $\mathrm{m}$. We estimate from the maximum elevation of this moraine that the equilibrium line altitude in the Judd stage was $780-800 \mathrm{~m}$. The outer moraine, which represents Kiernan's Timk stage, rises at $\sim 840 \mathrm{~m}$ behind the Judd moraine and descends parallel to it, but steepens and bifurcates at $\sim 750 \mathrm{~m}$. The eastern, more prominent part of the moraine descends to a steep nose around $650 \mathrm{~m}$, parallel to the Judd moraine (Fig. 2). Smaller moraines on the floor of Smith's Tarn valley represent minor glacial activity since retreat from the Judd moraine.

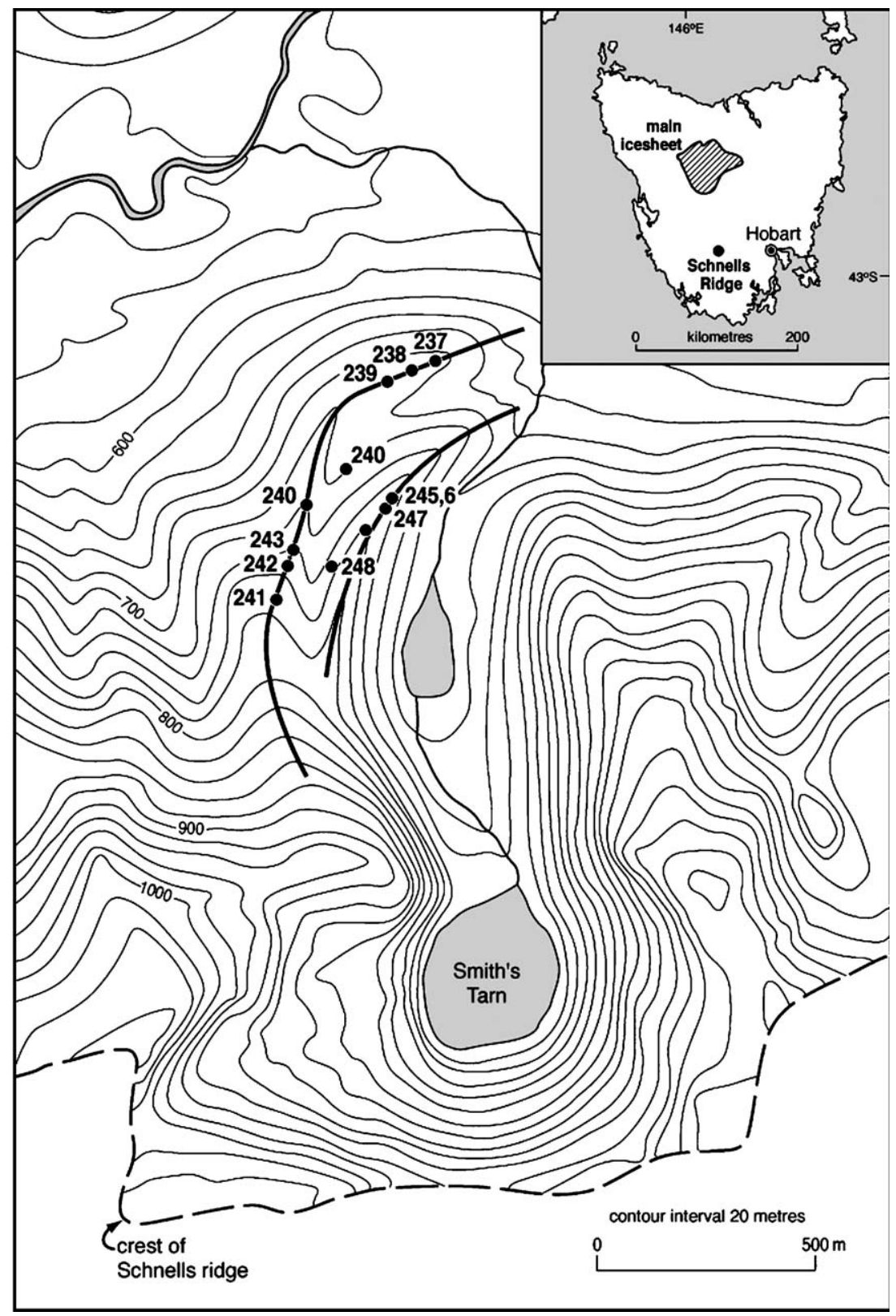

Fig. 1. Contour map and glacial features of the Smith's Tarn area on Schnells Ridge, showing locations of samples, numbered as in Table 1. Inset: Location in southwest Tasmania. 


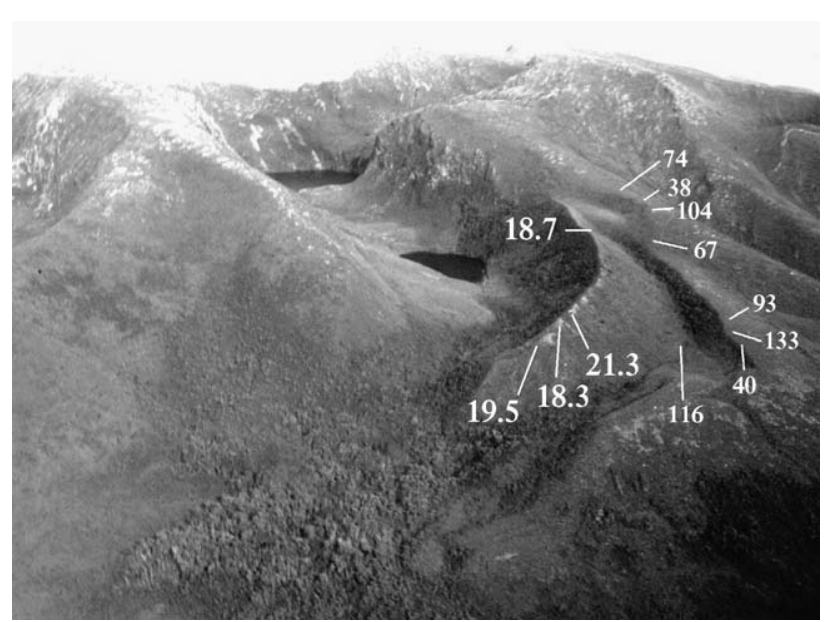

Fig. 2. Oblique aerial photograph showing Judd and Timk moraines with exposure ages (in thousands of years) of samples reported here, on the western shoulder of the Smith's Tarn valley (view from north; Judd moraine results shown in larger font).

The Timk moraine represents a glacier at least $110 \mathrm{~m}$ deep and about $700 \mathrm{~m}$ wide that terminated $\sim 580 \mathrm{~m}$ above present sea level. In the Judd advance the glacier terminated at $\sim 630 \mathrm{~m}$ altitude, was $\sim 400 \mathrm{~m}$ wide, and was $\sim 110 \mathrm{~m}$ deep at the trough exit.

\section{Methods}

Twelve samples of $\sim 1-2 \mathrm{~kg}$ weight were collected from the upper surfaces of large $(2-4 \mathrm{~m}$ diameter) quartzite blocks, four from the Judd moraine and eight from the longer ridge of the Timk moraine (sample sites: Fig. 1). Block tops typically were 0.7 to $1.0 \mathrm{~m}$ above the surrounding ground surface. Samples were crushed and sieved to 90 - to $150-\mu \mathrm{m}$ particle size and pure quartz was prepared following the general procedure of Kohl and Nishiizumi (1992). Typically, $30 \mathrm{~g}$ of purified quartz was dissolved in concentrated HF after spiking with $\sim 450 \mu \mathrm{g}$ of ${ }^{9} \mathrm{Be}$ from a solution prepared from deep-mined beryl. Beryllium was extracted using ion-exchange procedures and $\mathrm{BeOH}$ was coprecipitated with $\mathrm{Ag}_{2} \mathrm{CO}_{3}$. The mixture was dried, fired at $800^{\circ} \mathrm{C}$ to produce $\mathrm{BeO}$ dispersed in conductive silver matrix, and pressed into copper sample holders. AMS determinations were done with the ANU 14UD pelletron accelerator, at a terminal voltage of $8 \mathrm{MV}$ using the continuous beam-monitor technique (Middleton and Klein, 1987; Fifield, 1999) and a detector that stops ${ }^{10} \mathrm{~B}$ ions and detects ${ }^{10} \mathrm{Be}$ ions in the same gas volume (Fifield et al., 1990). Results were normalized to a ${ }^{10} \mathrm{Be} /{ }^{9} \mathrm{Be}$ value of $3.0 \times 10^{-11}$ for the NIST SRM4325 standard.

Exposure ages were calculated assuming a production rate of 5.02 atoms per gram of quartz/a at sea level and high latitude (Barrows et al., 2001; Gosse and Stone, 2001), which allows direct comparison between our results and those of Barrows et al. (2001). Scaling factors for altitude and latitude, adjusted for geomagnetic secular variation (Barrows et al., 2001), were taken from Lal (1991), assuming that the muon contribution at sea level was $3 \%$ of the spallation production. Small corrections were made for sample thickness and for slope/horizon shielding effects. Table 1 lists exposure ages. Corrections for postdepositional erosion of the rock surfaces are considered to be negligible, because the samples came from smooth, massive, and extremely hard quartzite blocks.

\section{Results and discussion}

The four samples from the Judd moraine gave statistically similar ages $(18,300-21,300 \mathrm{yr}$; Table 1$)$ with a mean of 19,200 $\pm 600 \mathrm{yr}$. Ages of the remaining eight samples, collected from the Timk moraine, ranged widely. Three samples from $740-770 \mathrm{~m}$ on the higher part of the moraine crest gave ages of 38,000,74,000, and 104,000 yr; a sample from the midridge rise at $720 \mathrm{~m}$ gave $67,000 \mathrm{yr}$; three samples from the lower part of the moraine crest at 670 $680 \mathrm{~m}$ gave $40,000,93,000$, and $133,000 \mathrm{yr}$; and a sample from the swale between the Timk and the Judd moraines gave $116,000 \mathrm{yr}$.

The Judd moraine represents the last major advance of the Smith's Tarn Glacier and is equated to the LGM in Australia (Kiernan, 1990). The mean age of 19,200 \pm 600 $\mathrm{yr}$ from the four concordant measurements closely agrees with LGM exposure ages of 17,000-20,000 yr reported by Barrows et al. (2002) from other glaciated sites in southeastern Australia.

In contrast, the Timk moraine apparently contains material from several advances. Alternatively, some of the sampled rocks may have been erosionally exhumed since

Table 1

Cosmogenic nuclide ages for glacial boulders from moraines on Schnells Ridge

\begin{tabular}{|c|c|c|c|c|c|}
\hline Location & $\begin{array}{l}\text { ANU } \\
\text { Be No. }\end{array}$ & $\begin{array}{l}\text { Altitude } \\
\text { (masl) }\end{array}$ & $\begin{array}{l}{\left[{ }^{10} \mathrm{Be}\right] 10^{6}} \\
\mathrm{~A} / \mathrm{g} \text { quartz }\end{array}$ & $\begin{array}{l}\text { Age } \\
\left(10^{3} \mathrm{yr}\right)\end{array}$ & $\begin{array}{l}\text { Error }^{\mathrm{a}} \\
\left(10^{3} \mathrm{yr}\right)\end{array}$ \\
\hline \multicolumn{6}{|l|}{ Judd moraine } \\
\hline Crest & 245 & 750 & $0.169 \pm 0.007$ & 19.5 & 0.9 \\
\hline Crest & 246 & 750 & $0.163 \pm 0.013$ & 18.3 & 1.4 \\
\hline Crest & 247 & 760 & $0.193 \pm 0.018$ & 21.3 & 2.0 \\
\hline Off-crest slope & 248 & 750 & $0.167 \pm 0.009$ & 18.7 & 1.0 \\
\hline \multicolumn{6}{|l|}{ Timk moraine } \\
\hline Crest & 237 & 680 & $0.342 \pm 0.019$ & 40 & 3 \\
\hline Crest & 238 & 685 & $1.196 \pm 0.048$ & 133 & 6 \\
\hline Crest & 239 & 685 & $0.828 \pm 0.032$ & 93 & 4 \\
\hline Swale & 240 & 700 & $1.059 \pm 0.037$ & 116 & 5 \\
\hline Crest & 241 & 770 & $0.673 \pm 0.020$ & 74 & 3 \\
\hline Crest & 242 & 750 & $0.339 \pm 0.024$ & 38 & 3 \\
\hline Crest & 243 & 740 & $0.983 \pm 0.048$ & 104 & 6 \\
\hline Midridge rise & 244 & 720 & $0.616 \pm 0.023$ & 67 & 3 \\
\hline
\end{tabular}

${ }^{a}$ Errors do not include uncertainty in production rate. 
deposition of the moraine. The sampled blocks were of similar heights above the ground surface $(0.7-1.0 \mathrm{~m})$, but the spatially random scatter of ages suggests that some have been erosionally exhumed. Apparent exposure ages for the Timk moraine range to $133,000 \mathrm{yr}$ (Table 1), suggesting a penultimate glacial age. However, several of the younger results correspond to exposure ages reported from moraines elsewhere in the region. Samples ANU Be 237 and $242(40,000 \pm 3000$ and $38,000 \pm 3000 \mathrm{yr})$ are similar to ages of 39,000-46,000 yr reported from other southeast Australian moraines by Barrows et al. (2001, 2002) and from southern New Zealand (Aurora-4, 40,00041,000 yr; Williams, 1996). Dates of 67,000 \pm 3000 and $74,000 \pm 3000 \mathrm{yr}$ from the higher part of the Timk moraine suggest an advance $\sim 70,000 \mathrm{yr}$ ago, similar to the early Kosciuszko glaciation in Australia's Snowy Mountains dated to MIS 4 by Barrows et al. (2001) and the Aurora-6 advance in New Zealand described by Williams (1996). Thus, we cautiously suggest that the Timk moraine was built during the penultimate glaciation but was reoccupied during the last glacial cycle. However, as differential exhumation cannot be ruled out, further sampling is required.

Finally, our results allow calibration of weathering rinds on subsurface dolerite boulders, previously used to estimate relative ages of moraines immediately north of Schnells ridge (Kiernan, 1990): rinds on dolerite boulders in Judd moraines around Lake Judd Valley are $1.2 \pm 0.3$ $\mathrm{mm}$ thick, and comparable thicknesses occur at other sites, including Lake Belton (Kiernan et al., 2001) and Lake St. Clair (Kiernan, 1991), both recently cosmogenically dated to the LGM (Barrows et al., 2002). In contrast, rinds in Timk stage moraines average $3.3 \pm$ $0.7 \mathrm{~mm}$ thick and are substantially thicker in Weld stage moraines (Kiernan, 1990). This confirms that, in the absence of dating, the likelihood of an LGM age for Tasmanian moraines may be estimated from weathering rinds on dolerite clasts.

\section{Acknowledgments}

We particularly thank Mr. A. Alimanovic for performing the lengthy sample purifications and AMS target preparations and Ms. K. Dancey for preparing Fig. 1.

\section{References}

Barrows, T.T., Stone, J.O., Fifield, L.K., Cresswell, R.G., 2001. Late Pleistocene glaciation of the Kosciuszko Massif, Snowy Mountains, Australia. Quaternary Research 55 (2), 179-189.

Barrows, T.T., Stone, J.O., Fifield, L.K., Cresswell, R.G., 2002. The timing of the Last Glacial Maximum in Australia. Quaternary Science Reviews $21,159-173$.

Colhoun, E.A., 1985. Glaciations of the West Coast Range, Tasmania. Quaternary Research 24, 39-59.

Fifield, L.K., 1999. Accelerator mass spectrometry and its applications. Reports on Progress in Physics 62, 1223-1274.

Fifield, L.K., Ophel, T.R., Allan, G.L., Bird, J.R., Davie, R.F., 1990. Accelerator mass spectrometry at the Australian National University's 14UD accelerator: experience and developments. Nuclear Instruments and Methods B52, 233-237.

Gosse, J.C., Stone, J.O., 2001. Terrestrial cosmogenic nuclide methods passing milestones towards paleo-altimetry. EOS, Transactions of the American Geophysical Union 82/7, 81-89.

Kiernan, K., 1990. The alpine geomorphology of the Mt Anne massif, southwestern Tasmania. Australian Geographer 21, 113-125.

Kiernan, K., 1991. Glacial history of the upper Derwent Valley, Tasmania. New Zealand Journal of Geology and Geophysics 34, 157-166.

Kiernan, K., Lauritzen, S.-E., Duhig, N., 2001. Glaciation and cave sediment aggradation around the margins of the Mt Field Plateau, Tasmania. Australian Journal of Earth Sciences 48, 251-263.

Kohl, C.P., Nishiizumi, K., 1992. Chemical isolation of quartz for measurement of in-situ-produced cosmogenic nuclides. Geochimica et Cosmochimica Acta 56, 3583-3587.

Lal, D., 1991. Cosmic ray labeling of erosion surfaces: in situ nuclide production rates and erosion models. Earth and Planetary Science Letters $104,424-439$.

Middleton, R., Klein, J., 1987. A new method for measuring ${ }^{10} \mathrm{Be} /{ }^{9} \mathrm{Be}$ ratios. Philosophical Transactions of the Royal Society A323, 121-123.

Williams, P.W., 1996. A $230 \mathrm{ka}$ record of glacial and interglacial events from Aurora Cave, Fiordland, New Zealand. New Zealand Journal of Geology and Geophysics 39, 225-241. 